\title{
EFFECT OF CHROMIUM PICOLINATE SUPPLEMENTATION ON GROWTH PERFORMANCE, SERUM BIOCHEMICACL PARAMETERS, AND IMMUNE STATUS OF BROILERS
}

\author{
T. I. Mohamed \& G. R. El-Sayed * \\ Dept. Of Nutrition And Nutrilional Deficiency Diseases \\ Dept. of Biochemistry And Chemistry of Nutrition * \\ Facully Of Vet. Medicine. Mansoura University
}

\begin{abstract}
Two hundred and forty broiler chicks lone dlay old). were randomly divided into four explal groups, each group was subdiwided to be in doublicate (30 chicks for each). Four levels of dietary chromium supplementation $(0$ control. 800,1600 , and $3200 \mu \mathrm{g} / \mathrm{Kg}$ ) wert: provided in the form of chromium plcolinate tivougl wout the experimental period 6 we'ks). The chicks were fed on starter diet (23\% CP \& $3200 \mathrm{Kcal} \mathrm{ME/Kg)} \mathrm{for} \mathrm{the} \mathrm{first} 3$ weiks and grower-finisher diet (20\% CP \& $3200 \mathrm{Kcal} \mathrm{ME/Kg)} \mathrm{through} \mathrm{the} \mathrm{next} \mathrm{lliree}$ weeks. Dody weight and feed intake were determined and feed conversion ratio tuas calculated. At the end of experiment, blood samples were collected for obtaining clear sera which were used for deternination of the total proteins, albumin. globulin. gli. cose. triacylglyoerol. lugh derssity lipoprotein (HDL), low density lipoprotein (LDI). phospholipids and non estrified free falty acids (NEFFAs). ALso, liver funcllon ellzymes including aspartate aminotransferase (AST), alanine anunotransferase (ALT) and ganuna glutamyl transferase (GGT) were determined. In addition, serum samples were used for determination of haemaggluthation infibition titer against Newcastle disease. $\gamma$ globulin. IgG and IgM. At end of the experiment. five birds from each replicate were used for detemination of carcass traits and compositton. The obtained results revealed that feeding high chromdum levels $(1600$ and $3200 \mu \mathrm{g} / \mathrm{Kg})$ significantly increased (P<0.05) the final body uxeght and aternge dally weight gain. Howcuer. chromium had no 4 (fect on feed conversion. The dietary supplements of chromum $(1600,3200 \mu \mathrm{g} / \mathrm{Kg})$ significantly reduced the blood glucose, the tatal cholesterol Level, LDL and NEFFAs. Also, chromium supplements (1600 and $3200 \mu \mathrm{g} / \mathrm{Kg}$ ) increased senum phosphollpids. HDI. total proteins, albumin and globulin. The llver functlon lests (AST, ALT and GGT) indicaled no differences belween the dlfferent groups. High chromturn supplementation
\end{abstract}




\section{T. I. Mohamed \& G. R. El-Sayed}

11600 and $3200 \mu \mathrm{g} / \mathrm{Kgl}$ increcsed the $\gamma$ globulin levels. Hacmagglutination inhibition antibody tiler against Newcestle vaccine. IgG and IgM were increased with increasing the chronium level in the diets. The carcass yield did not affected by chromium supplementration (1600 and $3200 \mu \mathrm{g} / \mathrm{Kg}$ ). There were decrease in the abdaninal pad and increuse in breast yield at the ketel of 1600 and $3200 \mu \mathrm{g} / \mathrm{Kg}$ of chronium. The protein percent of carcass was increased and fat percent was decieased while the ash and moisture uvere not significantly affected.

\section{INTRODUCTION}

Irrvaledil chromiun is hivolved in carbohydrate melabolism and recognkzel as active component of ghlurosc tolcrance factor (Rosebrough and Steele. 1981). It has been reported thal chromlum plays an important role in reguhating slucose unctabolisul in human and laboralory animals (Mertz, 1993). Chromium faclitates interaclion between insulin and insulin recepturs (Mooradian and Morley, 1987), and involved in lipld. proteln and nuclele acid metabolism (Orada et al., 1984; Ohba et al.. 1986; Press et al., 1991; McCarty, 1991; Page. 1991; Leln et al.. 1999). Cell prollleralion and synthesis of regulatory protein lom the basls of an elfecllve tmmune responsc. It can be alferted by dietary throminm as improved mmme responsc has becn obstrved when organic forms of chromium were supplemented to stressed fecrler calves (Chang and Mowrt, 1992; Moonsie-Shagecr and Mowat, 1993) and to daity cows (Burton et al., 1993).

Strcsics ancl discases bolh Increased urinary excretiun of chromfun (Borel et al., 1984; Anderson et al., 1988) and nay exacerbate a marglnal cliromlum deficiency. Therefure, defieicicy of trivalent chromlum may oceur in chicken under siress condition because of melibolic elianges medlaled by varions stressors. Cliromium deficiency may slow growth rate. limpair glucose lolerance ancl ullimately lead to clabetes or eoronary heart discase (Sicaonoff et al., 1984). So. chromium is recognized as an cssentlal trace clement for hmman and NRC (1989) has recominended an Intake of 50 to $200 \mu \mathrm{g} / \mathrm{Kg}$ of trivalent chromium lor the adult humbur. llowever. an ippropriale reconmendation of the chromlun requilement of poultry has not been made (NRC. 1994). because of poor absorption nl chromlum chloride which was largely used as a chromlun supplement in the carly studles (Dowling et al., 1989; Lien et al., 1996). Several investlgators have demonstrated that the effect of chromlum chloride is Insignificant as a diclary supplement (LI and Stoecker, 1996; Llen et al., 1996).

Chrominum pleolinate, an organic and low toxic lorm of trivalent chromlum lan stimulate msul!n iclivily (Evans, 1989; Walker, 1993; Amolkon et al., 1996). Organte chromium iul- 


\section{T. I. Mohamed \& G. R. El-Sayed}

proved immune response and in reised the (-)hromitun concentration in the kidncy and spleen (Anderson and Kozlovsky. 1985; Anderson et al., 1993 : Mooney and Chromwell 1997). Plant products contain a low contenl of chroulum. iniplying that broilers may have deficicury of chromium betatuse their dicts mostly are of plant ingredicnts (Glbon 1989). Poulliy requlred higher icvels of chromilum because (1)-cells of pancreas of poultry are not being active as thase of mammials and sccreting a small amount of tusulin (Lien et al., 1993; 1996: Ward et al., 1994). Therelore. the present study is to investlgatc the eflects of dietary snpplementation levels of

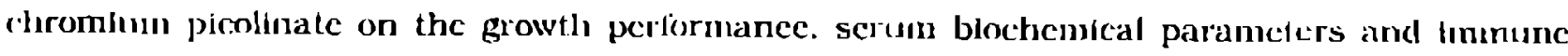
response.

\section{MATERIALS AND METHODS}

(wo lundrerl and forty broiler chicks (one day old). were equally divided al randon into lour

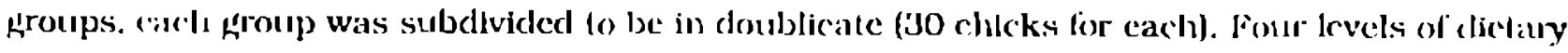
chromium supplementation 10 cuntrol. 800.1600 , and $3200 \mu \mathrm{g} \mathrm{Cr} / \mathrm{Kg}$ ) were provicled in the lorn of rhomium pleolinate. The broilers were ralsed for 6 wecks in a pen with natural ventlllaIton. The chicks were fed on slarker dief $123 \% \mathrm{CP} \& \mathrm{~J} 200 \mathrm{Keal} \mathrm{ME} / \mathrm{Kg}$ ) for the lirst I weeks and grower- lunisher diet $(20 \% \mathrm{CP} \& 3200 \mathrm{Kcal} \mathrm{ML/Kg}$ ) lhrougl the next three weeks (table. I) .

The leed and water were provicled ad-libitum. The birds werr vacelnated against Neweaslle disease virus using Hitchener and LiaSola vacenes at 7 and 14 days of alfe. respectively. Body welght ancl leed intake were detcrmined and the feed conversion ratio was calculated. Al cnd of

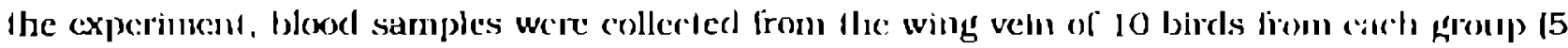
birds for (anch replicate). Blood samples were ccintrifuged for obtaining clear scha which wcre used for cle-lchunination of total proteins (Comel et al., 1949), albumin (Doumas, 1971). globuIn ( sthblatcling albumin from total protelns). glucose (Trinder, 1969). Irlacylfalyccrols (Young and Postaner, 1975), total rholcslcrol (Melatt/n1, 1978). IIDL (Clark et al, 1983). L.UL. (Friedwald et al.. 1973). phosphollpids (2llversmit, and Davis, 1950) and NEFFAs (Duucombe. 1964). Liver lincllon tests includilug AST. ALT (Reltman and Frankel, 1957) and GGT I Persljn and Vonderk, 1976) were detcmined. IRegardiab the Immune response. He serum samples were userl lise determination of lacmasylutination inhibition titcr against Newcistle cliscase (Anon, 1980), $\gamma$-ghobulin (Davis and Ornisteln, 1964). IgG and IgM (Erhard et al., 1992).

At end ol tle experlment. five birds from each replicale were: weighed. shitughtered innd used for studying the carcass fralls and cunposliton accordlng to AOAC (1984). The ablained dati were allalyzed using one way ANOVA lesl (Senedecor and Cochran, 1989). 
Table (1) : Physical and chernical composition ol experimental diel

\begin{tabular}{|c|c|c|}
\hline Ingredients & $\begin{array}{c}0-3 \text { weeks } \\
(\%)\end{array}$ & $\begin{array}{c}3-6 \text { weeks } \\
(\%)\end{array}$ \\
\hline Ground yellow corn & 53.96 & 63.82 \\
\hline Soybean meal(44\%) & 30.00 & 23.10 \\
\hline Fish meal $(72 \%)$ & 7.25 & 6.12 \\
\hline Soybean oil & 5.63 & 4.00 \\
\hline Limestone & 0.91 & 0.88 \\
\hline Dicalcium phosphate & 1.72 & 1.53 \\
\hline Sodium chloride & 0.30 & 0.30 \\
\hline Vil.\& min. premix & 0.25 & 0.25 \\
\hline DL-Methionine & 0.07 & $\cdot$ \\
\hline \multicolumn{3}{|l|}{ Calculated value *“ } \\
\hline $\mathrm{ME}(\mathrm{Kcal} / \mathrm{Kg})$ & 3200 & 3200 \\
\hline Crude protein \% & 23.0 & 20.0 \\
\hline Calcium \% & 1.00 & 0.90 \\
\hline Available phosphale \% & 0.45 & 0.40 \\
\hline Lysine :o & 1.33 & 1.12 \\
\hline Methionine \% & 0.50 & 0.39 \\
\hline
\end{tabular}

- Vilamin and mineral premix per $2.5 \mathrm{Kg}$ supplied ine following; Vitamin A, $3.5 \times 10^{6} \mathrm{IU}$ : Vitarmin $D 5 \times 10^{5} \mathrm{IU} ;$ vitamin E, $25000 \mathrm{IU}$; vitamin $K, 150 \mathrm{mg}$; ribollavin $1000 \mathrm{mg}$; panlothenic acid, $3000 \mathrm{mg}$; niacin, $7000 \mathrm{mg}$; choline, $3.5 \times 10^{5} \mathrm{mg}$; biolin, $50 \mathrm{mg}$ : lolic acid, $150 \mathrm{mg}$; vitamin $B_{12} 3.0 \mathrm{mg}$; thiamin, $500 \mathrm{mg}$; pyridoxine, 800 $\mathrm{mg}: \mathrm{Cu}, 50 \mathrm{~g} . \mathrm{Fe}, 100 \mathrm{~g} ; \mathrm{Mn}, 70 \mathrm{~g}: \mathrm{Zn} .50 \mathrm{~g}$ i iedine, $350 \mathrm{mg}$ and selenium, $150 \mathrm{mg}$. The producer recommended $2.5 \mathrm{Kg}$ promixl lon diel).

*. Values are calculaled according to leed composition lable ol NRC (1994). 


\section{T. I. Mohamed \& G. R. El-Sayed}

\section{RESULTS AND DISCUSSION}

The effects of feeding the diets supplemented with different levels of eluromitum pitulinate on brailer prolormance are presented in lable 2, liecding the diets suppiemented whth chromimn picollnatc al the level of 800 mg had no signifleance elfect on bocly weight. feed intakc and leed conversion. white the high chrmmilnu kevels (1600 and $3200 \mu \mathrm{g} / \mathrm{Kg}$ ) slgnifieantly increased $(P<0.05)$ the final body weight and the average dislly weight galn. Klm et al., (1996) reported that supplementation of 100 to $800 \mathrm{mg}$ chmmium picolinate / Kg diet did nol alliect frowth perlormance of brollers. Also, previous investigations found no response in broiler growll perfermance wheu dictary supplements of 100 in 400 mps duromium picolinalc / Keg were uscel (Lein et al., 1993; Ward et al., 1994: Mortozona, et al., 1998; Hegazl et al., 2001). Furlluenore. Leln et al., (1999) reported that a dietary level of $800 \mu \mathrm{g} / \mathrm{Kg}$ chromium picolinite clid not affect frowlh performance of bruller but higher levels of chromium improved lla tooly weight and average weight galu. In manumalian shıdies. dietary supplements of 200 mis chromiIIm plcolintalte / Kg dict tended to enhance the growlh rates of pigs and calves (Chang and Mowat, 1992; Moonsle-Shageer and Mowat, 1993; Lindemann et al., 1995). 'The (litlerence between broilers and mammals in $1 \mathrm{crm}$ of elfectiveness of chromium supplementatlon inight be attributcd to that pancreatle $\beta$-cells in poultry not being are active as those in mamnals (Llen et al., 1999). Irrercased wcight galn conkl be due to chromium action via redurtion of serIIrI corllsol decreasing its calabolle cflect (Brockman, 1986). In addition to chromium sole in metabulic proecss. It has been reported that chromium afled nuclear protchn synthests (Okada et al., 1984). Also. the increased average dally weight gain in brotlers fed hifh chrominm-diet. may be elice to increase dally fecel intake. howeves, chromium did not alfect lecel conversion matio (table, 2). Sinilar results were reported by Hossain et al., (1998) who found that orgitulc chromlum supplententation increased the body weight gain of broilers but did not alfect feed converslon.

'the effect of fecding diels supplemented with dllferent levels of chromium on scrum biochemical parauncters and liver finctlon lests are shown in lible, 3. The obtained results cxhibited that

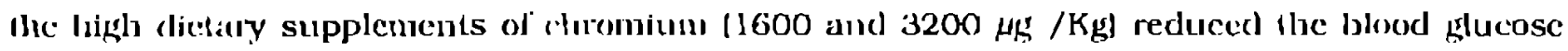
kevel. This may be through stimulation of the blological activily of Insulis by increasing Insulinsensitive cell receptors or blnding activily (Anderson et al., 1991: Morrls et al., 1993: Ward et al., 1994). Plisma insulin concentration was reported to be increased incarly. whereas corlicus-

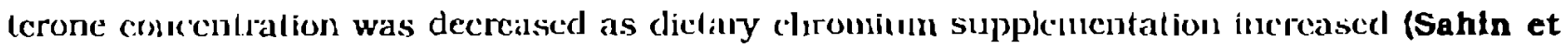
al. 2001). Contisol pronotes ghuconcogeresis and recluces glucosc utilizalion [Weekes, 1991). Insulin can stinulate glucose uptake and ulillzalion lsy cclls (Cupo and Donaldson, 1987). Re-

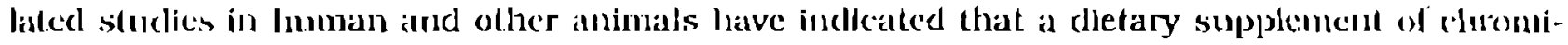




\section{T. I. Mohamed \& G. R. El-Sayed}

um reduced the serum glucose (Lefavi, et al., 1993; Mertz, 1993; Amolkon, et al., 1995; Lein et al., 1996; 1999).

The results of the prescnt study (lable, 3) Indicatcd that chromlum supplements $(1600$ and $3200 \mu \mathrm{g} / \mathrm{Kg}$ ) Inercased serum tolal proteins. albumin and globulln. These results are supported by Hegaxi et al. (2001) who lound chrominm picollnatc hncreased senm tolal protelns. It has been reportcd that chromlum had an effect on nuclcar proteln and RNA synthcsis (Okada et al.. 1984: Chang and Mowat, 1992). This Increase in protein level may be due to the anabolic effect of insulin.

The dlclary chronslum plcolinale supplements (1600 and $3200 \mu \mathrm{g} / \mathrm{Kg}$ ) significantly reduccd (P<0.05) the serum levels of total cholcsterol. LUL and NEFFAs while increascd levels of both phospholipids and HDL. These fndings may explain the role of chromlum in decreasing the lncldence of coronary heart discase in human (Stmonofr et al., 1984). Sindlarly. McCarty (1991) found that the chromlum Inercased the HDL level of human scrum. Howard et al., (1993) Jndlcated that insulin incrcased liver LDL receptors, so reducing the LDL lcvel in scrum. Leln et al., (1999) noliced that high chromium levels in diets of brollers increascd the scrum phospholipids while both tolal cholcsterol and triacylglycerol were not aflected. On the othcr hand. Hegazl et al.. (2001) found that ehromium picsilnatc reduccd the serum total lipids and total cholcsterol. The chromiun acts as actlvator of the biologlcal activity of Insulln which depresses adipocyte 11polysis by reducing the activity of cAMP and homone sensitive lipase (Lambert and Jacqucmln. 1979). Moreover, Pigs fed thromlum pieolnate supplemented ration had lower plasma NEFFAs concentration than control plgs (Mattbews, et al., 2001). The liver functinn tests Indlcated no diffcrence between the differcnt groups in AST. ALT and GGT (table, j). Gursoy (2000) mentoned that organic chromlum is more avallable. sale and has less toxdc eftect.

The effects of chromlum plcolinate supplementation on the Immune response of broilers are presenled in table. 4. High chromium supplementation $(1600$ and $3200 \mu \mathrm{g} / \mathrm{Ku}$ ) increased the rglobulin levels. Also. haemagglutination Inhlbition antibody tller against Newcastle vacclne. IgG and IgM were Increased with Increasing the chromlum level in the diet. Simllarly. Chang and Mowat (1992) found that chromitum plcolinate supplementation Increased total immunoglobulins and lgM. However, Moonsle-Shageer and Mowat (1993) reported that chromlum supplementation had no effect on $\mathrm{IgM}_{\mathrm{M}}$ and $\mathrm{IgG}_{2}$ levels but slgnifeantly Increased IgG 1 . Improv. ing the Immune response may be due to the effeet of chromium on reduction of cortisol, whieh has Immunosuppressive eflect and inhlbiting producllon and aetivlties of cytokines and antibod-

les (Kelly, 1988; Kegley and Spears, 1995). In addition, chromlum supplementation in stressed anlmals ean prevenl urinary lusses of zinc. Imn, copper, manganesc and selenlum (Schrauzer et al., 1986; Anderson et al., 1988). The deflcleneles of such minerals had been re- 


\section{T. I. Mohamed \& G. R. El-Sayed}

ported to lower resistancc to diseases (Bull, 1990).

Conceming the eflcet of chromlum supplementation on the carcass traits (table, 5), It was found thal carcass weight but not carcass yield was increascd by chronlun supplementation at the lcvels of 1600 and $3200 \mu \mathrm{g} / \mathrm{Kg}$ diet. Also, therc was a decrease in the abdominal fat pad and an Increase in hreasl yleld at lise lovel of 1600 and $3200 \mu \mathrm{g} / \mathrm{Kg}$ of chromlum supplementation. Moreover. the protein pereent of carcass was increased and fat percent was decreased while the ash and nolsture were not signilheantly different, Hossain et al., (1998) and Choet (1999) found that abdominal fat decreased and brepst meat yleld Increased in brollers fod diets supplemented with chromium picalinate at kevels of 300 and 500ppb, respectlvcly. Evang and Bowman (1992) and Kum et al.. (1996) demonstrated that the incrcase In protein content of brotlcr carcass nay be attributed to the effect of insnlin on amino acid uptake. Additionally. Lein et al. (1999) mentioned that chrominm increased the liver lipid accumulation so decreasing atecumulation of liat in abdominal pad.

Collcclively lion the rcsult of the prescnt study, it could be concluded that chronitum picollwate supplementation at a level of $1600 \mathrm{ppb}$ lor broiler diets has beneffeial eflects evidenccd by Improved growth performance and carcass liaits as wcll as improving the immunc response. It also has beneficlal consequences in terms of enhanced resistance to diseascs by enhancing the ellectivencss of vacelnes. 


\section{T. I. Mohamed \& G. R. El-Sayed}

Table (2) : Ellect ol chromium picolinale supplementation on performance of broilers (Mean \pm SE)

\begin{tabular}{|l|l|l|l|l|}
\hline \multirow{2}{*}{\multicolumn{1}{|c|}{ Ite...s }} & \multicolumn{4}{|c|}{ Supplemental chromium $(\mu \mathrm{g} / \mathrm{Kg}$ dlet) } \\
\cline { 2 - 5 } & \multicolumn{1}{|c|}{ Control $(0)$} & \multicolumn{1}{c|}{800} & \multicolumn{1}{c|}{1600} & 3200 \\
\hline Initial body weight & $35.04 \pm 0.19$ & $35.18 \pm 0.25$ & $35.1 \pm 0.28$ & $34.8 \pm 0.21$ \\
Final body weight $(g)$ & $1920 \pm 51.26^{\mathrm{b}}$ & $2165 \pm 42.33^{\mathrm{ab}}$ & $2280 \pm 46.51^{\mathrm{a}}$ & $2265 \pm 35.29^{\mathrm{a}}$ \\
Average daily gain (g) & $44.88 \pm 1.29^{\mathrm{b}}$ & $50.71 \pm 1.12^{\mathrm{ab}}$ & $53.45 \pm 0.85^{\mathrm{a}}$ & $53.1 \pm 1.65^{\mathrm{a}}$ \\
Average daily leed intake $(\mathrm{g})$ & $86.17 \pm 3.26^{\mathrm{b}}$ & $94.83 \pm 3.12^{\mathrm{ab}}$ & $101.2 \pm 4.28^{\mathrm{a}}$ & $98.77 \pm 3.8^{\mathrm{a}}$ \\
Feed Conversion ratio & $1.92 \pm 0.25$ & $1.87 \pm 0.19$ & $1.89 \pm 0.28$ & $1.86 \pm 0.25$ \\
\hline
\end{tabular}

ab Means in the same raw with no common superscripl are signilicantly different $(P<0.05)$.

Table (3) : Ellecl of chromium picolinale supplementation on serum biochemical parameters (Mean $\pm S E$ ) ol broiler chickens.

\begin{tabular}{|l|l|l|l|l|}
\hline \multirow{2}{*}{ Blochemical parameters } & \multicolumn{3}{|c|}{ Supplemental chromium $(\mu \mathrm{g} / \mathrm{Kg}$ diet) } \\
\cline { 2 - 5 } & \multicolumn{1}{|c|}{ Control (0) } & \multicolumn{1}{|c|}{1600} & \multicolumn{1}{c|}{3200} & 3200 \\
\hline Glucose (mg/dl) & $179.13 \pm 2.1^{\mathrm{a}}$ & $166 \pm 2.44^{\mathrm{a}}$ & $123.5 \pm 1.78^{\mathrm{b}}$ & $124.17 \pm 2.11^{\mathrm{b}}$ \\
Total proteins (gm/dl) & $5.70 \pm 0.22^{\mathrm{b}}$ & $6.78 \pm 0.4^{\mathrm{b}}$ & $9.97 \pm 0.38^{\mathrm{a}}$ & $11.04 \pm 0.17^{\mathrm{a}}$ \\
Albumin (gm/dl) & $2.97 \pm 0.31^{\mathrm{b}}$ & $4.15 \pm .35^{\mathrm{b}}$ & $6.25 \pm 0.29^{\mathrm{a}}$ & $7.33 \pm 0.32^{\mathrm{a}}$ \\
Globulin (gm/dl) & $2.73 \pm 0.28^{\mathrm{b}}$ & $2.63 \pm 0.21^{\mathrm{b}}$ & $3.72 \pm 0.32^{\mathrm{a}}$ & $3.71 \pm 0.25^{\mathrm{a}}$ \\
Triacylglycerol (mg/dl) & $30.51 \pm 1.46$ & $27.97 \pm 1.45$ & $28.4 \pm 1.28$ & $27.68 \pm 1.53$ \\
Tolal cholesterol (mg/dl) & $89.66 \pm 2.84^{\mathrm{a}}$ & $79.23 \pm 2.31^{\mathrm{b}}$ & $76.19 \pm 3.11^{\mathrm{b}}$ & $78.35 \pm 1.9^{\mathrm{b}}$ \\
Phospholigids (mg/dl) & $98.69 \pm 2.56^{\mathrm{b}}$ & $103.81 \pm 3.1^{\mathrm{b}}$ & $119.37 \pm 2.3^{\mathrm{a}}$ & $121.23 \pm 2.4^{\mathrm{a}}$ \\
HDL (mg/dl) & $68.83 \pm 1.19^{\mathrm{ac}}$ & $74.15 \pm 1.36^{\mathrm{b}}$ & $82.92 \pm 2.13^{\mathrm{a}}$ & $85.15 \pm 1.98^{\mathrm{a}}$ \\
LOL (mg/dl) & $26.16 \pm 0.85^{\mathrm{a}}$ & $21.03 \pm 0.72^{\mathrm{b}}$ & $19.25 \pm 0.53^{\mathrm{b}}$ & $15.09 \pm 0.66^{\mathrm{c}}$ \\
NEFFA (mg/dl) & $26.18 \pm 2.1 \mathrm{a}^{\mathrm{a}}$ & $24 \pm 1.60^{\mathrm{a}}$ & $14.8 \pm 1.1^{\mathrm{b}}$ & $6.6 \pm 0.23^{\mathrm{c}}$ \\
ALT(U/L) (U/L) & $40.21 \pm 2.45$ & $41.33 \pm 1.52$ & $39.33 \pm 1.29$ & $42.09 \pm 1.0^{5}$ \\
AST(U/L) & $20.43 \pm 1.80$ & $21.67 \pm 0.69$ & $23 \pm 0.82$ & $23.36 \pm 0.98$ \\
GGT (U/L) & $8.87 \pm 0.63$ & $9.12 \pm 0.35$ & $9.47 \pm 0.27$ & $9.41 \pm 0.26$ \\
\hline
\end{tabular}

abc Means in the same raw with no common superscript are signilicantly difterenl $(P<0.05)$ 
T. I. Mohamed \&2 G. R. El-Sayed

Table (4) : Effect of chromium picolinate supplementalion on immune response (Mean \pm SE) of broiler chickens.

\begin{tabular}{|l|l|l|l|c|}
\hline \multirow{2}{*}{ Iten.u } & \multicolumn{4}{|c|}{ Supplemental chromium $(\mu \mathrm{g} / \mathrm{Kg}$ diet) } \\
\cline { 2 - 5 } & \multicolumn{1}{|c|}{ Control (0) } & 800 & 1600 & 3200 \\
\hline Hl titre & $2.93 \pm 0.13^{\mathrm{c}}$ & $4.37 \pm 0.23^{\mathrm{b}}$ & $7.49 \pm 0.38^{\mathrm{a}}$ & $7.41 \pm 0.26^{\mathrm{a}}$ \\
Y-Globulin (gm/d) & $0.85 \pm 0.07^{\mathrm{b}}$ & $0.88 \pm .11 \mathrm{~b}$ & $1.36 \pm 0.08^{\mathrm{a}}$ & $1.44 \pm 0.09^{\mathrm{a}}$ \\
$\operatorname{lgG}(\mathrm{mg} / \mathrm{dl})$ & $589.14 \pm 25.7^{\mathrm{c}}$ & $597.59 \pm 36.7^{\mathrm{b}}$ & $845.64 \pm 40.36^{\mathrm{a}}$ & $838.58 \pm 17.6^{\mathrm{a}}$ \\
$\operatorname{lgM}(\mathrm{mg} / \mathrm{dl})$ & $154.21 \pm 8.83^{\mathrm{c}}$ & $196.11 \pm 6.79^{\mathrm{b}}$ & $238.33 \pm 12.8^{\mathrm{a}}$ & $274.18 \pm 17.6^{\mathrm{a}}$ \\
\hline
\end{tabular}

abc Means in the same raw with no common superscripl are signilicantly diflerent $(P<0.05)$.

- HI values are $\log 2$ of the original liters.

Table (5): Effect of chromium picolinale supplementalion the carcass trials of broilers (Mean \pm SE)

\begin{tabular}{|l|l|l|l|l|}
\hline \multirow{2}{*}{ Items } & \multicolumn{4}{|c|}{ Supplemental chromlum $(\mu \mathrm{g} / \mathrm{Kg}$ diet) } \\
\cline { 2 - 5 } & \multicolumn{1}{|c|}{ Control (0) } & \multicolumn{1}{|c|}{800} & 1600 & 3200 \\
\hline Carcass weight (gm) & $1295 \pm 39.02^{\mathrm{b}}$ & $1435 \pm 32.14^{\mathrm{ab}}$ & $1519 \pm 34.03^{\mathrm{a}}$ & $1515 \pm 26.16^{\mathrm{a}}$ \\
Carcass yield (\%) & $67.44 \pm 3.29$ & $66.28 \pm 3.35$ & $66.62 \pm 2.94$ & $66.88_{ \pm} 3.68$ \\
Abd. Fat pad (\% of carcass) & $3.84 \pm 0.34^{\mathrm{a}}$ & $3.61 \pm 0.28^{\mathrm{a}}$ & $2.58 \pm 0.30^{\mathrm{b}}$ & $2.62 \pm 0.41^{\mathrm{b}}$ \\
Breast yield (\% of carcass) & $20.1 \pm 1.96^{\mathrm{b}}$ & $20.7 \pm 1.38 \mathrm{ab}$ & $21.73 \pm 1.64^{\mathrm{a}}$ & $21.65 \pm 0.97^{\mathrm{a}}$ \\
Carcass composition & & & & \\
Moislure \% & $63.21 \pm 4.40$ & $62.35 \pm 4.35$ & $64.91 \pm 3.81$ & $63.46 \pm 0.81$ \\
Protein \% & $18.23 \pm 1.74^{\mathrm{b}}$ & $18.69 \pm 1.82^{\mathrm{ab}}$ & $19.89 \pm 1.59^{\mathrm{a}}$ & $19.94 \pm 1.63^{\mathrm{a}}$ \\
Fat \% & $16.26 \pm 1.30^{\mathrm{a}}$ & $16.32 \pm 0.89^{\mathrm{a}}$ & $13.66 \pm 1.12^{\mathrm{b}}$ & $14.06 \pm 0.92$ \\
Ash \% & $1.8 \pm 0.17$ & $1.79 \pm 0.31$ & $1.82 \pm 0.21$ & $1.89 \pm 0.30$ \\
& & & & \\
\hline
\end{tabular}

ab Means in the same raw wllh no common superscript are significantly dilleront $(P<0.05)$. 


\section{REFERENCES}

Amoikon, E. K.; Fernandez., J. M.; Southern, L. L.; Thompson, D. L.; Ward, T. L. and O1cott, : M. (1995) : Ellect of chromluni tripicolinate on growth, glucose tolerance, instulln sensitivity, plasma melabolites and growth hormone in pigs. J.Anim. Scl. 73: 1123.

Anderson, R. A.; Bryden, N. A. and Polansky, M. M. (1993) : Form of chromíum affects tissue chromlum concentration. FASEB, J. 7: A204.

Anderson. R. A.; Bryden, N. A.; Polansky, M. M. and Deuster, P. A. (1988) : Exerclse eflects on chromium cxeretion of trained and untralned men consuming constant, dict. J. Appl. Physlol. 64:249.

Anderson, R. A. and Kozloveky. A. S. (1985) : Chromium intake, absorption and cxeretion of silbjects consuming scll-selected dlets. Anı. J. Clin. Nut. 41: 1177- 1183.

Anderson, R. A.; Polansky, M. M.; Bryden, N. A. and Canary. J. J. (1981) : Supplemental cliromium effects on glucose. insulin. glucagon and urnary cbromlum losses in subjecls consumlng controlled low chromlum dets. Amerlcan J. of Clinlcal Nutrtion, 54: 909-916.

Anon (1 30 ) : Isolaton and Identilication of avlan pathogens. Amencan Assuctation of nvlan Pathologists, Texas. USA.

AOAC (1984) : Ometal methods of analysis (14th Ed.). Association of ofliclal analylical chemists. Washington D.C.

Borel, J. S.: Majerus, T. C. ; Polansky, M. M.; Mozer, P. B. and anderson, R. A. (1984) : Chromlum Intake and Cr excretion of trauma patlents. Biol. Trace Elem. Res.. 6:317.

Brockman, R. P. (1986) : Pancreatic and adrenal hormonal regulation of metabolism. In: L.P. Milligan . W. L. Grovum, and A.D. Dobson (Ed,) Control of digestlon and metabollsm in ruminants. P. 405. Prenticc-Hall. Englewood Clills, N.J.

Bull, R. C. (1990) : Trace clement and immunlly. Western Nutr. Conf. P 33. Calgary. Alberta, Canada.

Burton, J. L.: Mallard, B. A. and Mowrat, D. N. (1993) : Effect of supplemental chromium on immune responses of Perlparturtent and early lactation dalry cows. J. Anim. Sel. 71 : 1532- 1539 .

Chang, $X$. and Mowat, D. N. (1992) : Supplemental chromium for stressed and growing fceder (alves. J. Anim. Scl. 70: 559-565. 


\section{T. I. Mohamed \& G. R. El-Sayed}

Choet. M. (1999) : Increasing emelency of lean tissue deposision in broller chickens. Rural Industry Rescarch \&developuicnt Corporation Project. NSW. Australia.

Clark, D. A ; Kozel. P. R. and Mosser, E. L. (1983) : Evaluation of a Kit to mcasure HDL-c in serun.. Clin. Chem., 29. 1311.

Cornel. A. G.: Baradwill. C. S. and David. M. M. (1949) : Colorlmetric determination of serum lolal protein. Blol. Chem. J.177,751-768.

Cupo, M. A. and Donaldson, W. E. (1987) : Chromlum and vanadium effect on glucose metabollsm and lipids synthesis in the chick. Poultry Scl. 66: 120-126.

Doumas. B. T. (1971) : Spectrophtometric Bromocresol bluc for determination of albumin In scrum. Clin. Chem.Acta.31.87-96.

Dowling, H. J.; Offenbacher, E. G. and Pi-Sunyer, E. X. (1989) : Absorption of Inorganlc trivakent chromium from the vascularly perfuse rat small Intestinc. J. Nutrition.119: 11381145.

Duncombe. W. G. (1964) : The colorimctric inlcro-delcrmination of non-esterifed free fatty acids in plasma. Clin. Chen, Acla, 9: 122-125.

Erhard, M. H.; Gulstrop, 1.; Jungling, A.; Kaspers, B.; Schmidt. P. and Kuhman, R. (1992) : Development of spectflc enzymc linked immunosorbent antlbody assay for dstection of illumunoglobulins G,M,A. Using monoclonal antibodies. Poultry Scl.. $71: 302-310$.

Evans, G. W. (1989) : The effect of chromlum plcollnate on insulln controlled parameters iu humans. Internalioual J. of Biophysical and Mcdical Rescarch. 11:163-180.

Evans, G. W. and Bowman, T. D. (1992) : Chromium Picollnate Increases membranc llukdity and rate of Insulin Internalization. J. of Inorganic chemlstry. 46: 243-250.

Frledorald, W. T. Levy, R. 1, and Frldrkeksonmen, H. (1973) : Eslimatton of LDL-c in plasma willsout ultracentrilugation. Clln. Chem. 18. 499-502.

Glbson, R. S. (1989) : Assesment of trace clement status in humans. Progress of liood and Nutrition Scl., 13: 67-111.

Gursoy, U. (2000) : Chromlum In broller dicts. Feed Iuternational 21, 24-27. A rcvlew.

Hegazi, S. M.: Bragda, Sh. Taha, and Abo-El-Magd, M. K. (2001) : Influenee of supplemented salbutanol and chromlum on growth performance and carcass quality of brollers.2nd Inlemational Conlerence, Faeulty of Vet.Medicine Mansoura Unlver'sity.

Hossain, S. M. Barrento, S. I. and Suva, G. G. (1998) : Growth performance and carcass utill- 


\section{T. I. Mohamed \& G. R. El-Sayed}

zallion of brofler feed supplemental chromiun from chromlum yeast. Anlmal lieed Scicnce and Technology, $71(3-4): 217-228$.

Howard, B. V.: Schnelderman, N.: Palkner, B.; Hefner, S. M. and Laws, A. (1993) : Insulln. licalth behavlours, and lipld nictaloollsin. Melabolism. 42 (9, 51): 25-35.

Kegley. E. B. and Spears, J. W. (1995) : hnmune response, glucose metabolisni, and performance of fceder calves leed Inorganlc or organic chromium. J. Antm. Scl. 73: 27212726.

Kelly, K. W. (1988) : Cross-talk betwecn Immnnc and cnducrine systern. J. Aním. Scl. 66: 2095.

Kim, Y. H.; Han, Jbn. K.; Choi, Y. J.: ShIn, I. S.; Shae, B. J. and Kang, X. H. (1996) : Efrects of dietary level of chronium plcolinate on growth performance. carcass qnality and serunil traits in broller chlicks. AJAS, 9: $341-374$.

Lambert, B. and Jecquemln, G. (1979) : Inlibition of epinephrine- Induced lipolysls In isolated white adipocyles of aghug rabbits by incrcased alpha- adrenergie nesponslveness. J. Lipid Res. 20: 208-216.

Lefavi, R. G. ; Wllson, J. D.; Keith, R. E.: Anderson, R. A.; Blegsing, D. L.: Hames,G. G. and MacMUan, J. L. (1993) : Lipid-lowering eflect of chromium (III) nIcolinic acld complex in male athletes. Nutrition Research. 13.: 239-249.

Leln, T. E.: Chen, S. Y., Chen, C. L. and Yu, C. P. (1993) : The effect of varlons levels of chronitum plcolinatc on growth performances and serum trafts of plgs. J. of Chinese Society Anlinal Sclence, 22: 349-357.

Leln. T. E.; Chen, S. Y.; Wu, C. P.; Lu, J. J. and Chou, R. G. (1996) : The eflect of supplemenlal chromlum picollnate on growth perfomances, serum traits and carcass eharacterlsties of plgs. J.of Chinesc Soclety animal sclence. 25: 253-260.

Leln, T. F.: Horng. Y. M. and Yang, K. H. (1999) : Perfornance, serum characteristies, careass traits and lipid metabolisn of brollers as allected by supplement of chromlun plcollnate. Brillsh Poultry Scicnce, 40: 357-363.

U, Y. C. and Stoecker, B. J. (1998) : Chromum and yogurt ellects on hepatic lipids and plasilla glugusc and Insulin ol lean and obese miee. Blological Trace clement Research, 9: 233-242.

Undemann, M. D.; Wood, C. M.: Harper. A. F. Kornegay, E. T. and Anderson, R. A. (1995) : Dietary chroinium pleolinate additions Improve galn: Feed and eareass charaeteristies in growing finlshing plgs and inerease lltter slze in reproducting sows. J.Anlm. Scl.73: 457-465. 


\section{T. I. Mohamed \& G. R. Elsayed}

Matthews. J. O.; Sauthern, L. L.: Fernandez, J. M.: Pontlf, J. E.; Bidner, T. D. and Odgaard, R. L. (2001) : Effect of chronilum picolinatc and chromium proplonate on glucose and Insulin kinetics of growing barrows and on growth and carcass traits of growinglinishing barrows. J. Anin. Sci. 79 (8): 2172-2178.

McCarty, M. E. (1991) : The case of supplemental chromlun and a survcy of clintcal studies with chromium plcolinate. J. Applied Nutrition, 43: 58-66.

Melattini, F. (1978) : Colorimetric determination of serum total cholcstcrol. Clin. Chem. 24. $2161-2165$.

Mertz, (1993) : Chromium in human mutrilion. A review. J. of Nutrition, 123: 626-6333.

Mooney. K. W. and Chromwel, G. L. (1997) : Elfeel of dlctary cliromlum picollnale supplementation on growth. earcass characteristics. and accretion rates of carcass tissues in growing finishlng swine. J. Anlm. Sci.73:3351-3357.

Moonsle-Shageer, S. and Mowat, D. N. (1993) : Ellect of level of supplemental chromlum picolinate on performance, semm constltuents and tumune status of stressed leeder calves. J. Anim. Scl.. 71 : 232-238.

Mooradian. A. D. and Morley. J. E. (1987) : Micronutrient status In diabetes mellitus. J.Clin.Nutr..45: 877.

Mords, B. W. ; Gray. T. A; and MacNell, S. (1993) : Glucose- dependent uplake of chromium in human and rat Insulin-sens|tive tissucs. Clinical Scienee, 84: 477-482.

Mortozona, Y.: Hatano, K.; Sugawara, N. and Ishlbashl, T. (1998) : Effecl ol diclary chromiuin pieollnate on growlh, careass quality, and serum lipids of fcmale broilers. Animal Science and Technology. 69:7, 659-665.

Natlonal Research Councll (1989) : Recommended dletary allowances. Washington, D.C. Nallonal Acadmy Press.

National Research Councll (1994) : Nutition Requlrement of Poultry. 9th Ed.Washingion. D.C. Nittonal Academy Press.

Obba. H.; Suzukl, Y. and Obba, H. (1986) : Enhancement of ribonuclelc acid synthesis by chromium (III)-bound chromatln. J. of Inorganle Blochemistry. 27: 113-119.

Okada, S.: Tuskada, H. and Ohba, H. (1984) : Enhancement of nueleo RNA synthesis by chromitum (III) In regeneraltng rat liver. J. of Inorganic Bloehemistry. 21:113-119.

Page, T. C. (1991) : Chromium, tyyptophan and pleolinate in dlets for plg and poultiy. A disseralion. Loulslana State University. USA. 


\section{T. T. Mohamed \& G. R. El-Sayed}

Persijn. J. P. and Vander. S. W. (1976) : Colorimeteric determination of $\gamma$ - glutanyl transeferase, J.Clin. Chem.Clin, Hioclicm., 14,421.

Preas, R. 1.; Geller. J. and Evans G. and Evans, G. W. (1991) : The effect or chromlum plcollnale ou scrum cholesterul and apolipoprotein fraction in human subjects. Western J. of Medicine, 152: 41-45.

Reitman, S. and Frankel, S., (1957) : Colorimetric determination of GOT or GPT actlvity. An. J. Clin. Path. 28,56

Rosebrough, R. W. and Steele, N. C. (1981) : Ellect of supplemental dietary chromiun or nicotinic aeld on carboliydrate metabolism during basal starvation and relceding periods in poultiy. Poultry Scienee, 60: 407-417.

Sabln, K.; Kucuk, and O.. Sahin N. (2001) : Ellcets of dictary chromlum picolinate sippplementalion on performance and plasma concentrations of insulin and corticosterone in laying he us under low anbicul tempcralure. J. Phys. Anlm. Nutr. 85. (5-6): 142.

Senedecor. G. W. and Cochran. P. W. (1989) : Statistical Methods. 8th ed., lowa State Universily. Press. Anes. I.A.

Shrauzer، G. N.; Sbregtha, K. P., Molenaar, T. B. and Meade. S. (1986) : Eflect of Cr supplementation on food utlization and the trace clement compositJon in the liver and heart of klucose- exposed young mice. Blol. Tiace Element Res، 9: 79.

Simonoff, M.; Llabador, Y. G.; Hamon, A: Peers, M. and SImlnoff, C. M. (1984) : low plasma rhromium in-paticnt wlth coronary artery and heart diseases. Blological Trace Elcment IResearch, 6:431-439.

Trlnder. P. (1969) : Determination of blood glucose using an oxldase-/74 peroxidase system with a non careinogenic chromagen. J.Clin. Path.22, 158-161.

Walker. M. (1993) : Chromlum; The essential mineral. Health of Foods Business 5: 51-52.

Ward. T. L.: Southern, L. L. and Boleman. S. L. (1994) : Effeet of dletary pleolinate on growth. nitrogen balance and body eomposition of growing broller chleks. J. Anim. Scl.. 73 (S. 1) : 37.

Weekes. T. E. (1991) : Homonal control of glucose inetabolism. In: T. Tsuda: Y.Sasaki; and R. Ritwashima (ed.) Physiological aspect of digestlon and metabolism In ruminants. Procecdlng in 7th Int. Symposlum on Rumlnant Physlology. P183.

Young, D. and Postaner, L. (1975) : Enzymatic and eolonmeteric test for determination of trigilycerides, Clin. Chem. $21,5$. 


\section{T. I. Mohamed \& G. R. El-Sayed}

Zliversmit, D. B. and Davlo. A. IT. (1950) : Micro-determination of phosoholipids by irfchloroacetic acid precipltation. J. Lab. ClIn. Med. 35. 155-160. 
:

تأثير إضافة بيكلونات الكروم على النمو والقياسات الكيميائية الحيرية وخصائص الذبيحة والمستوى المناعى فى دجاج التسمين

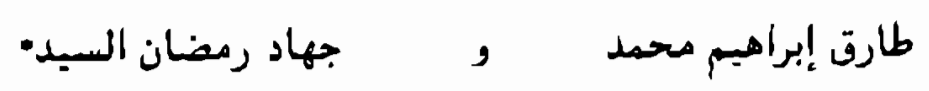

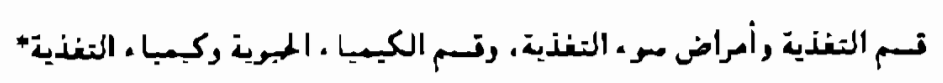

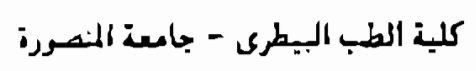

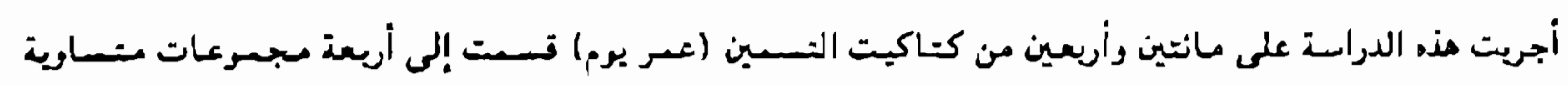

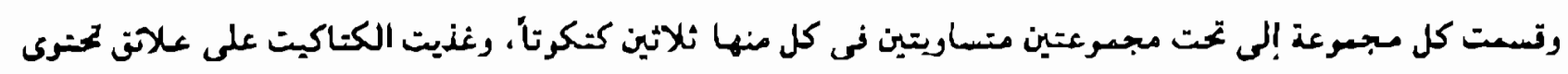

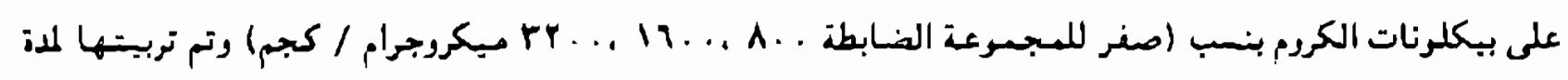

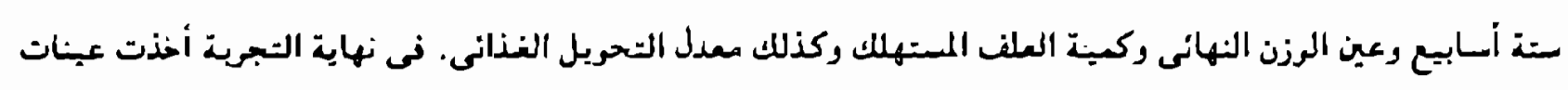

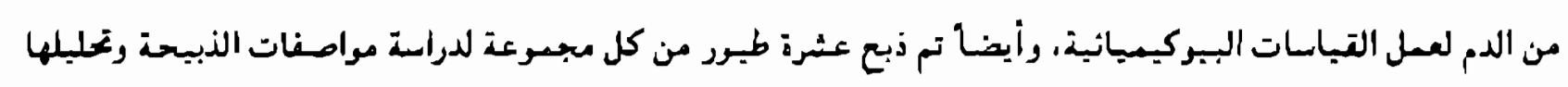
كيهيانيا.

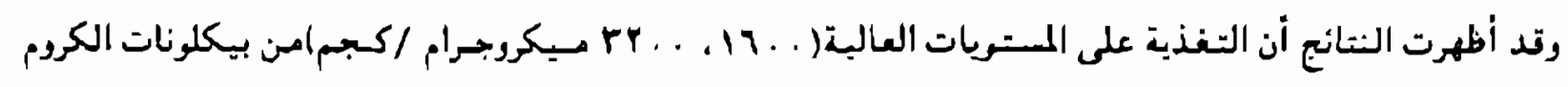

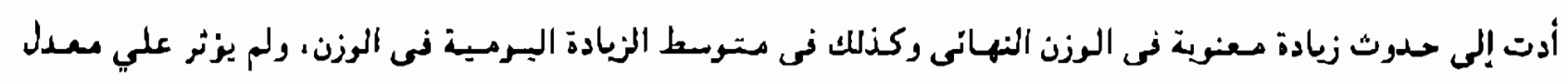
التحريل الغذائى.

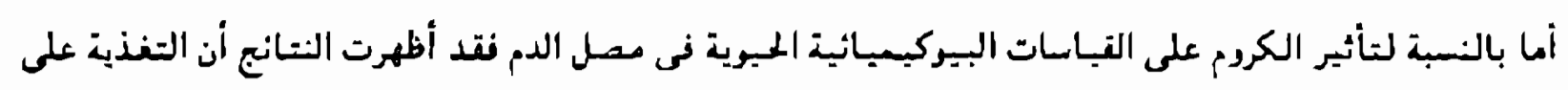

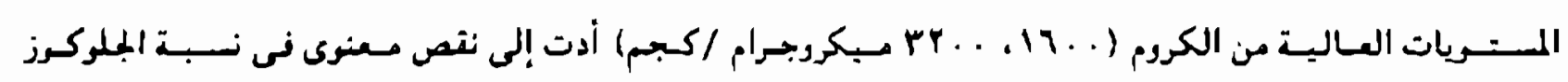

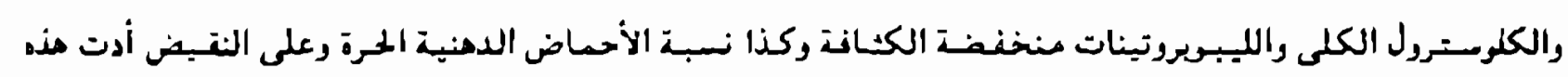

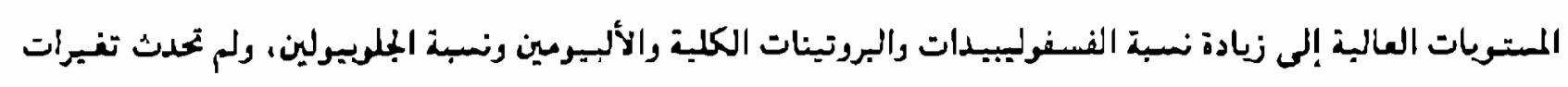

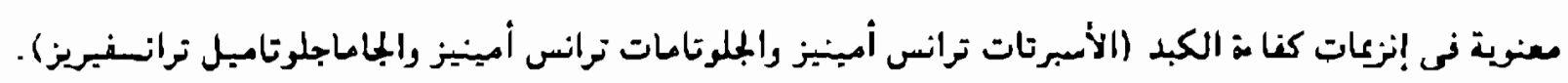
وجد أن تأثير إضانة الكروم على الزيادة فى وزن الذبيحة كان واضهأ حبث أنها زالدت بزيادة كمبة الكروم الضانة

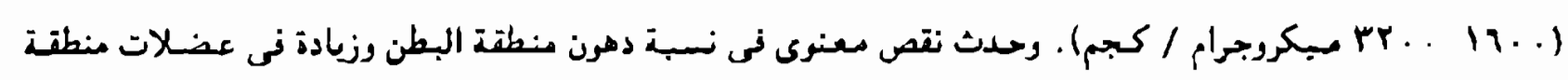




\section{T. I. Mohamed \& G. R. El-Sayed}

الصدر ، ورجد أن مناك زيادة فى نسبة البروتبنات رنقص فى نسبة الدمون فى الذبيسة رلكن لم يحدث تغـير فى نسبة الرطوية ركذا نسبة الأملاح.

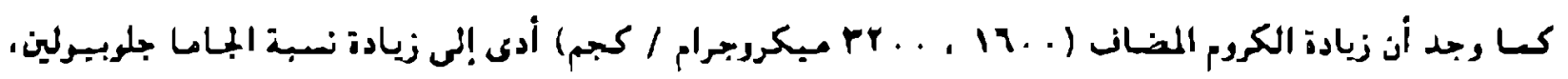

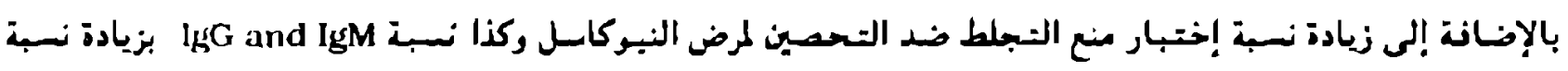
الكروم وجسنت المسترى المناعى للدجاج.

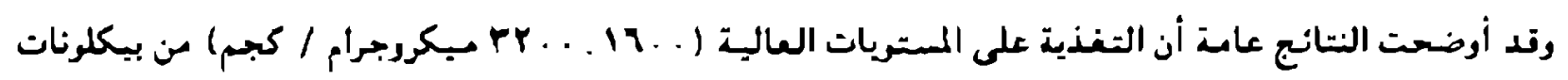

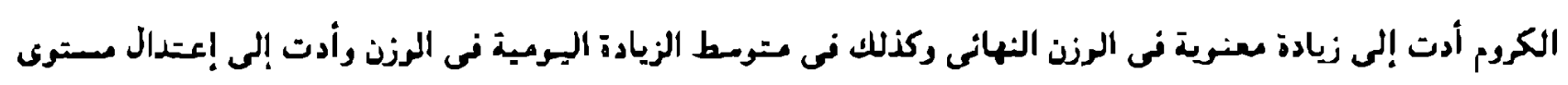

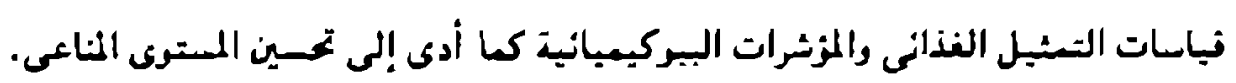

